\section{Target gene analyses of 39 amelogenesis imperfecta kindreds}

\author{
Chan H-C, Estrella NMRP, Milkovich RN, Kim J-W, Simmer JP, Hu JC-C. Target \\ gene analyses of 39 amelogenesis imperfecta kindreds. \\ Eur J Oral Sci 2011; 119 (Suppl. 1): 311-323. (C) 2011 Eur J Oral Sci
}

Previously, mutational analyses identified six disease-causing mutations in 24 amelogenesis imperfecta (AI) kindreds. We have since expanded the number of AI kindreds to 39 , and performed mutation analyses covering the coding exons and adjoining intron sequences for the six proven AI candidate genes [amelogenin $(A M E L X)$, enamelin $(E N A M)$, family with sequence similarity 83 , member $\mathrm{H}(F A M 83 H)$, WD repeat containing domain 72 (WDR72), enamelysin (MMP20), and kallikrein-related peptidase $4(K L K 4)$ ] and for ameloblastin $(A M B N)$ (a suspected candidate gene). All four of the X-linked AI families (100\%) had disease-causing mutations in $A M E L X$, suggesting that $A M E L X$ is the only gene involved in the aetiology of $\mathrm{X}$-linked AI. Eighteen families showed an autosomal-dominant pattern of inheritance. Disease-causing mutations were identified in $12(67 \%)$ : eight in $F A M 83 H$, and four in ENAM. No $F A M 83 H$ coding-region or splice-junction mutations were identified in three probands with autosomal-dominant hypocalcification AI (ADHCAI), suggesting that a second gene may contribute to the aetiology of ADHCAI. Six families showed an autosomalrecessive pattern of inheritance, and disease-causing mutations were identified in three (50\%): two in $M M P 20$, and one in WDR72. No disease-causing mutations were found in 11 families with only one affected member. We conclude that mutation analyses of the current candidate genes for AI have about a $50 \%$ chance of identifying the diseasecausing mutation in a given kindred.

\section{Hui-Chen Chan ${ }^{1}$, Ninna M. R. P. Estrella ${ }^{2}$, Rachel N. Milkovich ${ }^{1}$, Jung-Wook Kim ${ }^{3}$, James $\mathrm{P}$. Simmer ${ }^{1}$, Jan C-C. Hu ${ }^{1}$}

${ }^{1}$ Department of Biologic and Materials Sciences, University of Michigan School of Dentistry, Ann Arbor, MI, USA; ²Department of Orthodontics and Pediatric Dentistry, University of Michigan School of Dentistry, Ann Arbor, MI, USA; ${ }^{3}$ Department of Pediatric Dentistry \& Dental Research Institute, School of Dentistry, Seoul National University, Seoul, Korea

Jan C-C. Hu, Department of Biologic and Materials Sciences, University of Michigan Dental Research Lab, 1210 Eisenhower Place, Ann Arbor, MI 48108, USA

\section{Telefax: +1 734-9759329}

E-mail: janhu@umich.edu

Key words: ameloblastin; amelogenin; enamelin; enamelysin; kallikrein-related peptidase 4

Accepted for publication June 2011
Amelogenesis imperfecta (AI) is a group of hereditary conditions featuring the pathological formation of dental enamel. By the narrow definition used here, the phenotype is limited to the dental apparatus and is not associated with more generalized defects (1). Enamel malformations are categorized as hypoplastic, hypocalcified, or hypomaturation types $(2,3)$, which reflect the timing of the developmental disturbance. During the secretory stage of amelogenesis, the enamel layer achieves its final dimensions by the lengthening of enamel crystals (4). Hypoplastic (thin) enamel results from secretory-stage pathologies. During the maturation stage the enamel layer hardens by the widening and thickening of the crystals deposited during the secretory stage (5). Hypomaturation enamel has normal thickness, but is soft and contains residual protein as a result of maturation-stage disturbances. Hypocalcified $\mathrm{AI}$ is the most severe form of AI and may be the result of pathology starting in the secretory stage and continuing through maturation. When mode of inheritance is included in the classification, 14 subtypes of AI are recognized $(2,3)$. The complexity of the AI aetiology is suggested by the diversity of its phenotypes and its multiple patterns of inheritance.

Dental enamel formation is a specialized process. Unravelling the mechanisms of dental enamel formation requires knowledge of all critical molecular participants.
Determining the genes that cause syndromic and isolated AI provides this information. Identifying the genes that cause isolated AI narrows the focus to components that are most specialized for dental enamel formation. At the time of writing there were six proven candidate genes for AI: amelogenin (AMELX, Xp22.3-p22.1); enamelin (ENAM, 4q21); WD repeat containing domain 72 (WDR72, 15q21.3); family with sequence similarity 83, member H $(F A M 83 H, 8 \mathrm{q} 24.3)$; enamelysin (MMP20, 11q22.3-q23); and kallikrein-related peptidase 4 (KLK4, 19q13.4). The major secretory-stage enamel constituents (amelogenin, enamelin, ameloblastin, and MMP20) are thought to be specialized for tooth formation, as these genes degenerate in mammals that have lost, during evolution, the ability to make teeth or dental enamel (6-10).

At the Enamel VII conference (in 2005), we presented a paper that summarized the results of mutational analyses of 24 kindreds with isolated AI (11). At that time, only six of their disease-causing mutations had been identified. Since that report, new candidate genes for AI have been identified, and additional AI kindreds have been recruited. We now know the disease-causing mutations for 12 of the original 24 families and have ruled out the presence of coding region and splice junction mutations in the six known AI candidate genes plus ameloblastin $(A M B N)$ in the families where the genetic cause could not be determined. Here we report the results of mutation analyses in 
the original 24 and 15 additional AI kindreds and discuss them in the context of new information concerning normal and pathological enamel formation.

\section{Material and methods}

The human study protocol and patient consents were reviewed and approved by the Institution Review Boards at the University of Michigan.

Fifteen families with isolated enamel defects were recruited for genetic studies. Mutational analyses for $A M B N$ were conducted in all families. Based upon the enamel phenotype and pattern of inheritance, the most likely of the six proven candidate genes for AI (AMELX, ENAM, FAM83H, WDR72, MMP20, and KLK4) was selected and the coding exons and nearby intron sequences were amplified, using genomic DNA from each proband as the template. The amplification products were characterized by DNA sequencing and then other family members were tested to determine their genotype with respect to each sequence variation; however, typically there were too few people in each family for haplotype analyses. All subjects received an oral examination, and intra-oral photographs and dental radiographs were obtained.

In most cases, $10 \mathrm{ml}$ of peripheral whole blood was obtained from participating family members. Alternatively, buccal swabs were performed. Genomic DNA was isolated using the QIAamp DNA Blood Maxi Kit and protocol (Qiagen, Valencia, CA, USA). Genomic DNA (50 ng) from affected individuals was amplified using the Platinum PCR Supermix (Invitrogen, Carlsbad, CA, USA), and the amplification products were purified using the QIAquick PCR Purification Kit and protocol (Invitrogen). The concentration of purified amplimer was estimated by the intensity of its ethidium bromide-stained band on a $1 \%$ agarose gel. The DNA-sequencing reactions used $1.0 \mathrm{pmol} /$ $\mu \mathrm{l}$ of oligonucleotide primer and $3 \mathrm{ng} / \mu \mathrm{l}$ for each $1000 \mathrm{bp}$ of amplification product, and were analyzed using an ABI Model 3700 DNA sequencer (Applied Biosystems, Foster City, CA, USA) at the University of Michigan DNA sequencing core. The primer pairs and PCR conditions for the amplification of the coding regions were as previously described for $A M B N$ (11), AMELX (12), ENAM (13), FAM83H (14), WDR72 (15), KLK4 (16), and MMP20 (17).

\section{Results}

\section{Original 24 Al kindreds}

Disease-causing mutations in 12 of our original 24 AI kindreds (11) have been identified (Table 1). Two families showed an X-linked pattern of inheritance and both had AMELX mutations (12). Eleven families showed a dominant pattern of inheritance. Three of these families had ENAM mutations, and five had FAM $83 H$ defects. Five families showed recessive transmission. Six families had only a single affected individual (simplex pedigrees),

Table 1

Patterns of inheritance and amelogenesis imperfecta (AI) aetiologies of the 39 AI kindreds

\begin{tabular}{|c|c|c|c|c|c|c|c|}
\hline \multicolumn{2}{|c|}{ Not identified } & \multicolumn{6}{|c|}{ Mutation identified } \\
\hline No. & Pattern & No. & Pattern & Gene & cDNA & Protein & References \\
\hline \multicolumn{8}{|c|}{ Original 24 AI kindreds } \\
\hline 4 & Simplex & 1 & X-linked & AMELX & c. $2 \mathrm{~T}>\mathrm{C}$ & p.M1T & 12 \\
\hline 5 & Simplex & 2 & X-linked & $A M E L X$ & c. $11 \mathrm{G}>\mathrm{C}$ & p.W4S & 12 \\
\hline 6 & ADAI & 3 & ARAI & WDR72 & c.1467_1468delAT & p.V491fsX497 & 15 \\
\hline 9 & Simplex & 7 & ADAI & $F A M 83 H$ & c. $1 \overline{3} 30 \mathrm{C}>\mathrm{T}$ & p.Q444X & 19 \\
\hline 10 & ADAI & 8 & ADAI & $F A M 83 H$ & c. $1243 \mathrm{G}>\mathrm{T}$ & p.E415X & 64 \\
\hline 11 & ADAI & 12 & Simplex/AD & $F A M 83 H$ & c. $891 \mathrm{~T}>\mathrm{A}$ & p.Y297X & 64 \\
\hline 14 & Simplex & 13 & ADAI & ENAM & c. $(583-588+1)$ delG & p.R179-N196del & 13 \\
\hline 16 & ARAI & 15 & ARAI & MMP20 & c. $954-2 \mathrm{~A}>\mathrm{T}$ & IVS6-2A > T & 17 \\
\hline 18 & ARAI & 17 & ADAI & ENAM & c. $211-2 \mathrm{~A}>\mathrm{C}$ & p.M71_Q157del & 13 \\
\hline 20 & Simplex & 19 & ADAI & ENAM & c. $157 \mathrm{~A}>\mathrm{T}$ & p.K53X & 11 \\
\hline 22 & ARAI & 21 & ADAI & $F A M 83 H$ & c. $1380 \mathrm{G}>\mathrm{A}$ & p.W460X & 64 \\
\hline 23 & ADAI & 24 & ADAI & $F A M 83 H$ & c. $2029 \mathrm{C}>\mathrm{T}$ & pQ677X & 64 \\
\hline \multicolumn{8}{|c|}{ Additional 15 kindreds } \\
\hline 25 & ADAI & & & & & & \\
\hline 26 & ADAI & 33 & Simplex/AR & $M M P 20$ & c. $102 \mathrm{G}>\mathrm{A}$ & p.W34X & 18 \\
\hline 27 & Simplex & 34 & X-linked & $A M E L X$ & Gene deleted & p.0 & (here) \\
\hline 28 & Simplex & 35 & ADAI & FAM $83 H$ & c. $1192 \mathrm{C}>\mathrm{T}$ & p.Q398X & 19 \\
\hline 29 & Simplex & 36 & ADAI & ENAM & c. $647 \mathrm{G}>\mathrm{T}$ & p.S216L & 20 \\
\hline 30 & Simplex & 37 & X-linked & $A M E L X$ & c. $208 \mathrm{C}>\mathrm{A}$ & p.P70T & (here) \\
\hline 31 & Simplex & 38 & ADAI & $F A M 83 H$ & c. $2029 \mathrm{C}>\mathrm{T}$ & p.Q677X & (here) \\
\hline 32 & Simplex & 39 & ADAI & $F A M 83 H$ & c. $1354 \mathrm{C}>\mathrm{T}$ & pQ452X & (here) \\
\hline
\end{tabular}

A simplex inheritance pattern is when only one person in a kindred is affected, so the inheritance pattern appears to be recessive but could be a de novo or sporadic mutation. Note that one simplex case was found to be dominant and another was found to be recessive once the disease-causing mutation was identified.

$\mathrm{AD}$, autosomal dominant; ADAI, autosomal-dominant amelogenesis imperfecta; AMELX, amelogenin; AR, autosomal recessive; ARAI, autosomal-recessive amelogenesis imperfecta; ENAM, enamelin; FAM83H, family with sequence similarity, member H; $M M P 20$, enamelysin; WDR72, WD repeat containing domain 72 . 
so the pattern of transmission could not be determined. Simplex cases are usually recessive, but they can be the manifestations of de novo mutations with any inheritance pattern possible. Among the five families showing recessive transmission, we identified one disease-causing mutation in both alleles of MMP20 and one in both alleles of $W D R 72$. Among the six simplex cases, a disease-causing mutation was identified in a single allele of $F A M 83 H$, so the inheritance pattern in this simplex case was actually autosomal dominant. In addition to the six proven AI candidate genes, mutational analyses for $A M B N$ were performed for all of the probands, but no disease-causing mutations were identified in this gene.

Success in determining the causative mutation in these AI kindreds varied, depending upon the pattern of transmission. The disease-causing mutations were identified in both cases showing $\mathrm{X}$-linked inheritance $(100 \%)$. Among the 12 kindreds with dominant conditions (11 with a dominant pattern of inheritance and a dominant de novo mutation), disease mutations were characterized in eight $(67 \%)$. Among the five recessive conditions, only two $(40 \%)$ of the causative mutations were identified.

\section{Additional Al kindreds}

Fifteen additional AI kindreds were recruited and extensively, but not exhaustively, characterized. Of these additional kindreds, two were X-linked, six were dominant, and seven were simplex. Mutational analyses for the six AI candidate genes were prioritized based upon previously established genotype-phenotype correlations,

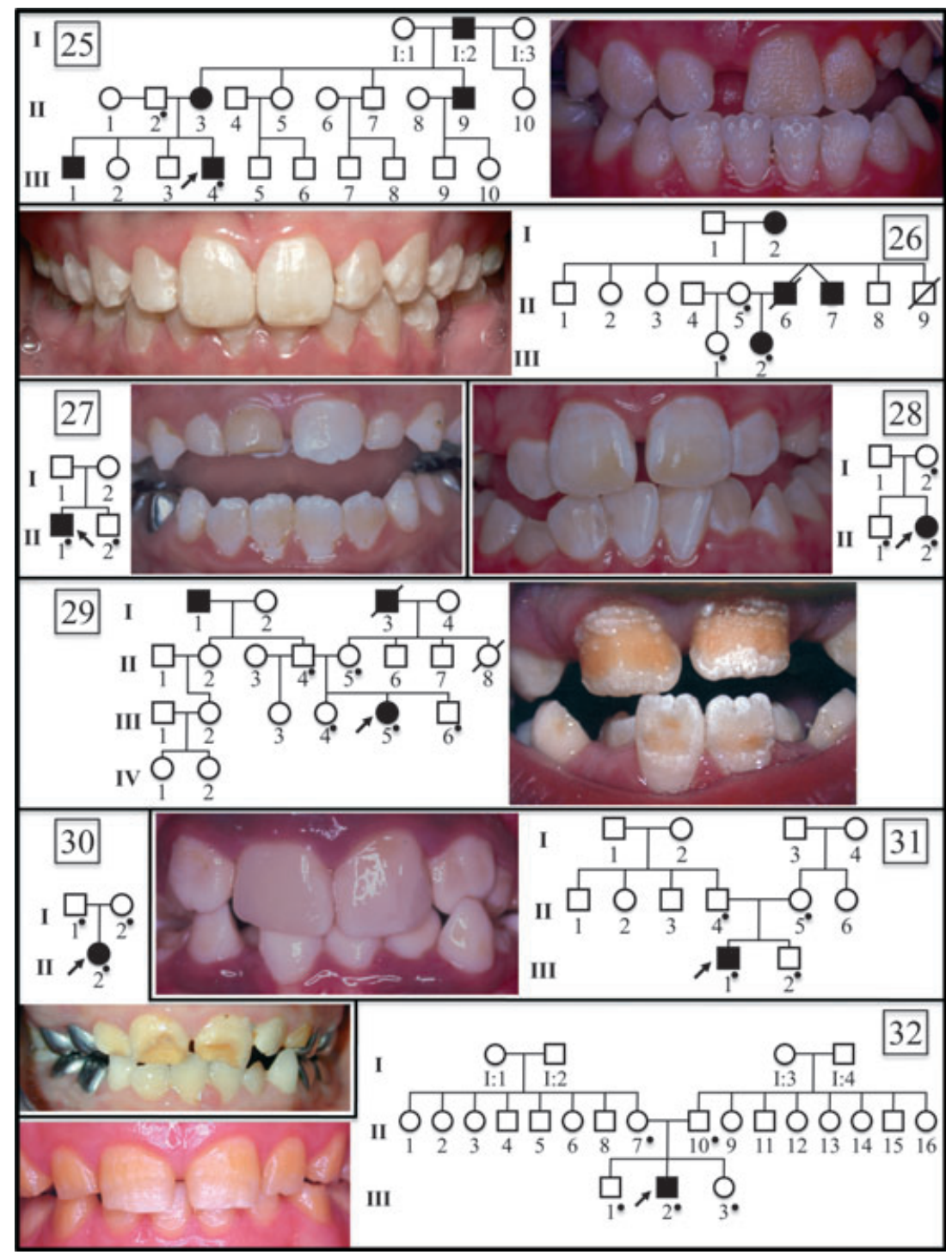

Fig. 1. Oral photographs of probands and pedigrees of eight amelogenesis imperfecta (AI) families of unknown aetiology. A dot on the pedigree marks subjects recruited in the study. Numbering starts with 25 , as a continuation of previous work reporting mutational analyses of 24 AI kindreds (11). Pedigree analyses showed that families 25 and 26 have a dominant pattern of inheritance. Families $27-32$ have either a recessive pattern of transmission or are de novo mutations. 


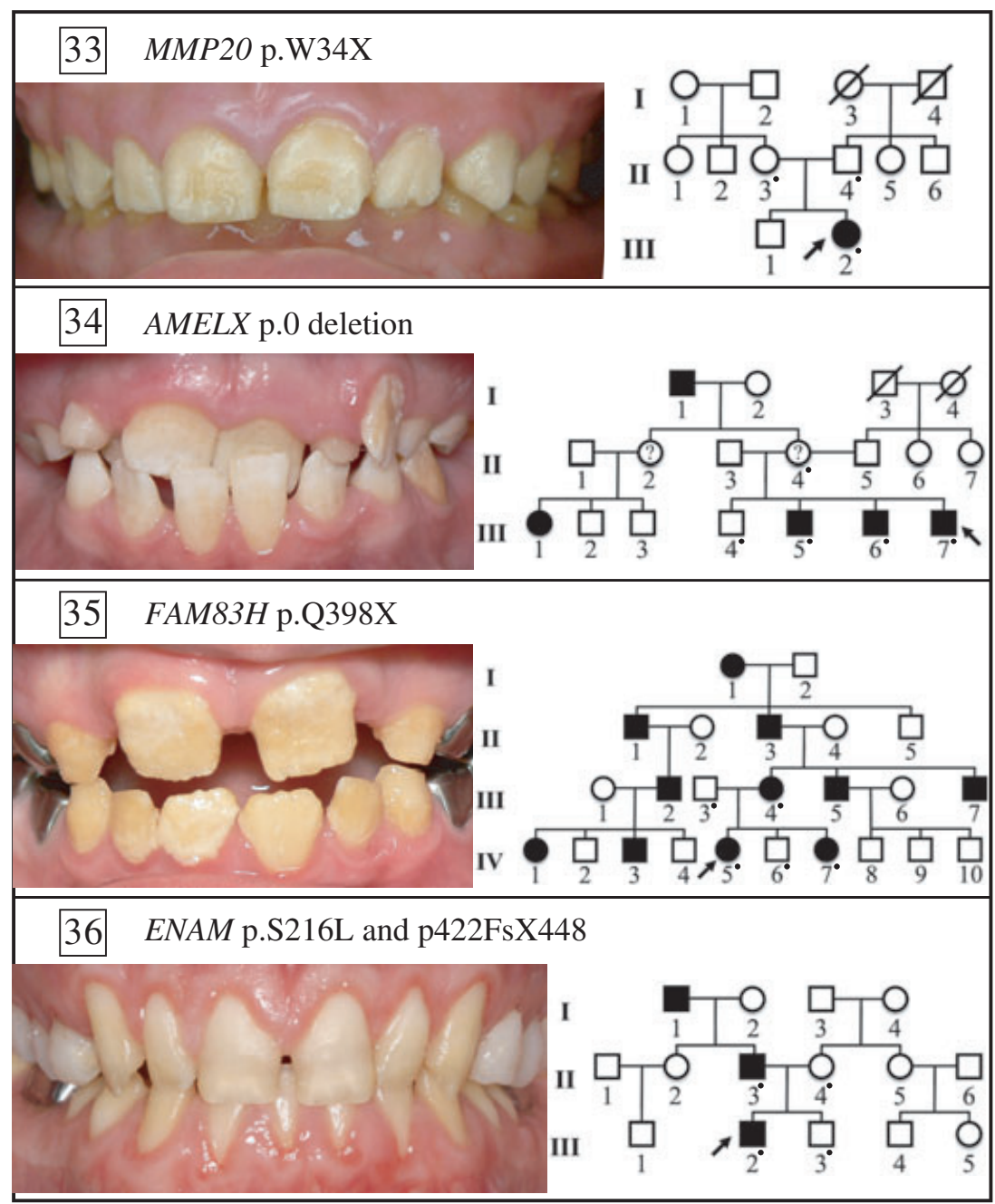

Fig. 2. Oral photographs of probands and pedigrees of four amelogenesis imperfecta (AI) families of known genetic aetiology. The proband of family 33 has autosomal-recessive hypomaturation AI, resulting from a p.W34X mutation in both enamelysin (MMP20) alleles (18). The proband of family 34 has X-linked dominant hypoplastic hypomaturation AI, resulting from a complete deletion of amelogenin $(A M E L X)(\mathrm{H}-\mathrm{C}$. Chan, unpublished data). The proband of family 35 has autosomal-dominant hypocalcified AI caused by a p.Q398X mutation in one allele of family with sequence similarity 83, member H (FAM83H) (19). The proband of family 36 has a severe form of hypoplastic AI resulting from different mutations (p.422FsX448 and p.S216L) in both enamelin $(E N A M)$ alleles (20). The father (p.422FsX448) and mother (p.S216L) had only one affected ENAM allele and both showed a very mild, but detectable, enamel phenotype.

and their transmission patterns were deduced from the pedigrees. Using this approach we were not able to identify a disease-causing mutation in eight of the 15 probands (Fig. 1). Among the seven remaining probands, four had novel mutations (Fig. 2), which included a nonsense mutation (p.W34X) in both alleles of MMP20 (18), a complete deletion of AMELX (H-C. Chan, unpublished data), a FAM83H nonsense (p.Q398X) mutation (19), and an ENAM compound heterozygote (p.S216L/p.422FsX448) (20). The final three AI kindreds in the new group were found to have previously identified disease-causing mutations: two had FAM83H nonsense mutations [p.Q677X (Fig. 3) and p.Q452X (Figs 4 and S1)], and one had an AMELX missense mutation [p.P70T (Figs 5, S2, and S3)]. Thus, in the 15 additional AI kindreds, both X-linked mutations
$(100 \%)$, four of the six dominant mutations $(67 \%)$, and one of the seven simplex mutations $(14 \%)$ were identified (Table 1).

Among the 39 AI kindreds characterized, diseasecausing mutations were identified in 19, so screening a given AI kindred for mutations in the six proven candidate genes has about a $50 \%$ chance of success. AMELX mutations were identified in all four of the X-linked families $(100 \%)$. Four ENAM and eight FAM83H mutations were identified among the 18 autosomaldominant families $(67 \%)$. One WDR72 and two MMP20 mutations were found among the six AI kindreds with known recessive conditions $(50 \%)$. In addition, there were 11 simplex cases in which the disease-causing mutation could not be identified by mutational analyses of the known candidate genes. 


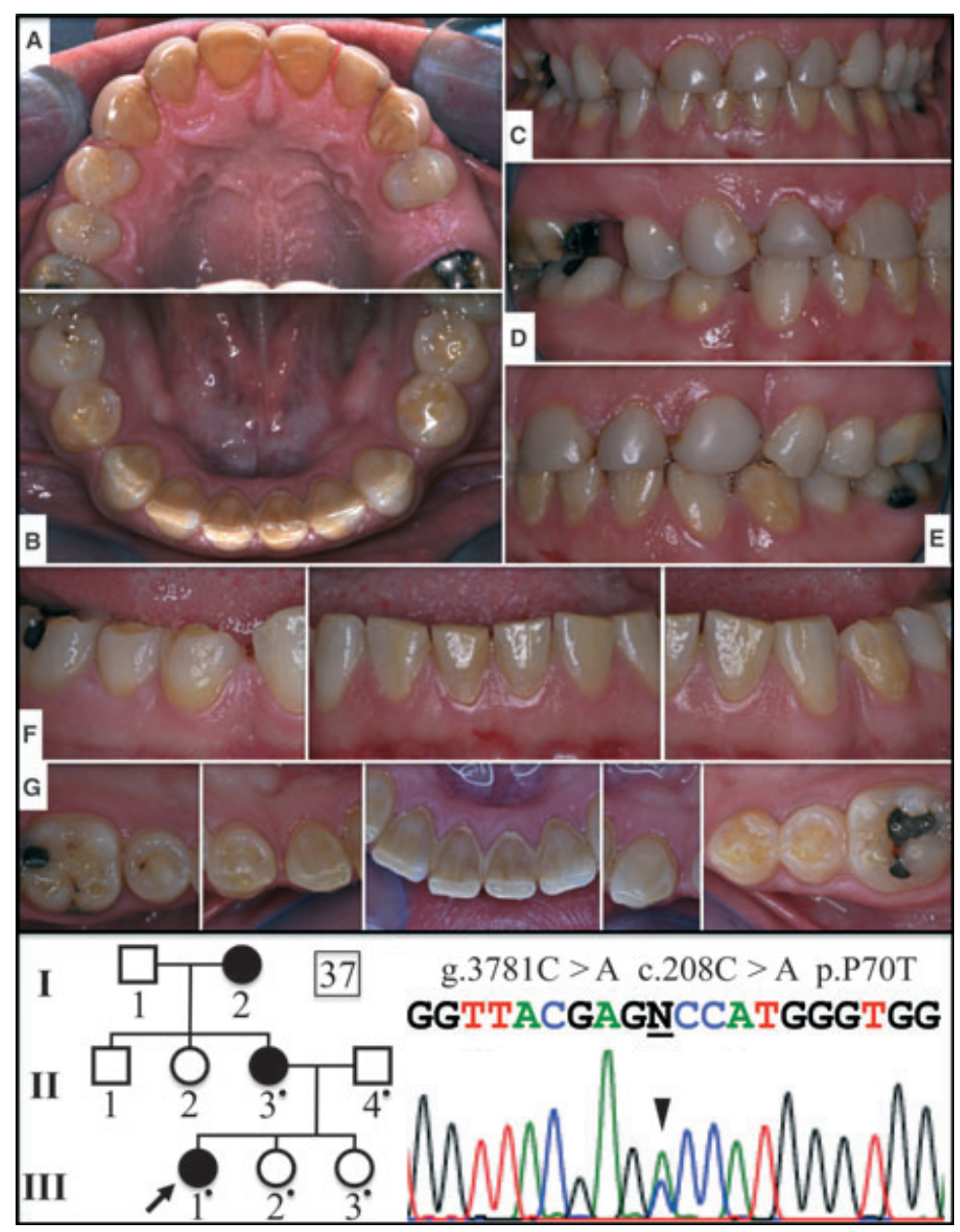

Fig. 3. Pedigree and sequencing chromatograms for family 37 [with the amelogenin $(A M E L X)$ missense mutation, p.P70T] and oral photographs of the proband's affected mother. The pedigree is consistent with an X-linked pattern of inheritance. The $A M E L X$ DNA sequencing chromatogram shows a doublet of C and A (c.208C > A; arrowhead). (A) Maxillary occlusal, (B) mandibular occlusal, (C) frontal, (D) right buccal, (E) left buccal, (F) frontal/buccal views of mandibular teeth, and (G) occlusal/incisal views of mandibular teeth.

\section{Discussion}

Screening the six proven AI candidate genes in kindreds with isolated AI has about a $50 \%$ chance of identifying the causative mutation, but the odds vary depending upon the pattern of inheritance. Next we discuss the findings of this study in the light of recent advances in our understanding of each form of AI according to its transmission pattern.

\section{X-linked Al}

About $5-10 \%$ of all AI cases are X-linked (21). Currently, 16 different $A M E L X$ mutations have been reported in subjects with X-linked AI (Table 2). If the AI is $\mathrm{X}$-linked, a mutation in $A M E L X$ is predictably found, suggesting that no other genes on the X-chromosome are involved in its aetiology. In all 16 AMELX mutations, the phenotype was limited to the enamel layer, excepting an open bite, which is probably a secondary effect as it is observed in all forms of AI, regardless of which gene is defective.
None of the reports that describe the dental phenotype resulting from defined AMELX mutations detected developmental abnormalities in the periodontium (cementum, periodontal ligament, and alveolar bone), despite the fact that such abnormalities would certainly have been diagnosed if they were part of the dental phenotype, given that dental examinations and radiographs are routinely used to characterize the dentition in patients with AI. In addition to there being no reports of developmental periodontal defects in individuals with AMELX mutations, there are solid data showing no, or only trace expression of amelogenin along developing tooth roots (22-24). These findings undermine the conclusions of an extensive and growing literature that describes amelogenin as a signalling molecule which serves important functions in the formation and healing of the periodontium.

As a rule, enamel malformations in X-linked AI are more severe in men than in women (who have a second copy of $A M E L X)$. Women often show vertical grooves in their enamel crowns. These are believed to result from alternating bands of ameloblasts secreting normal and 


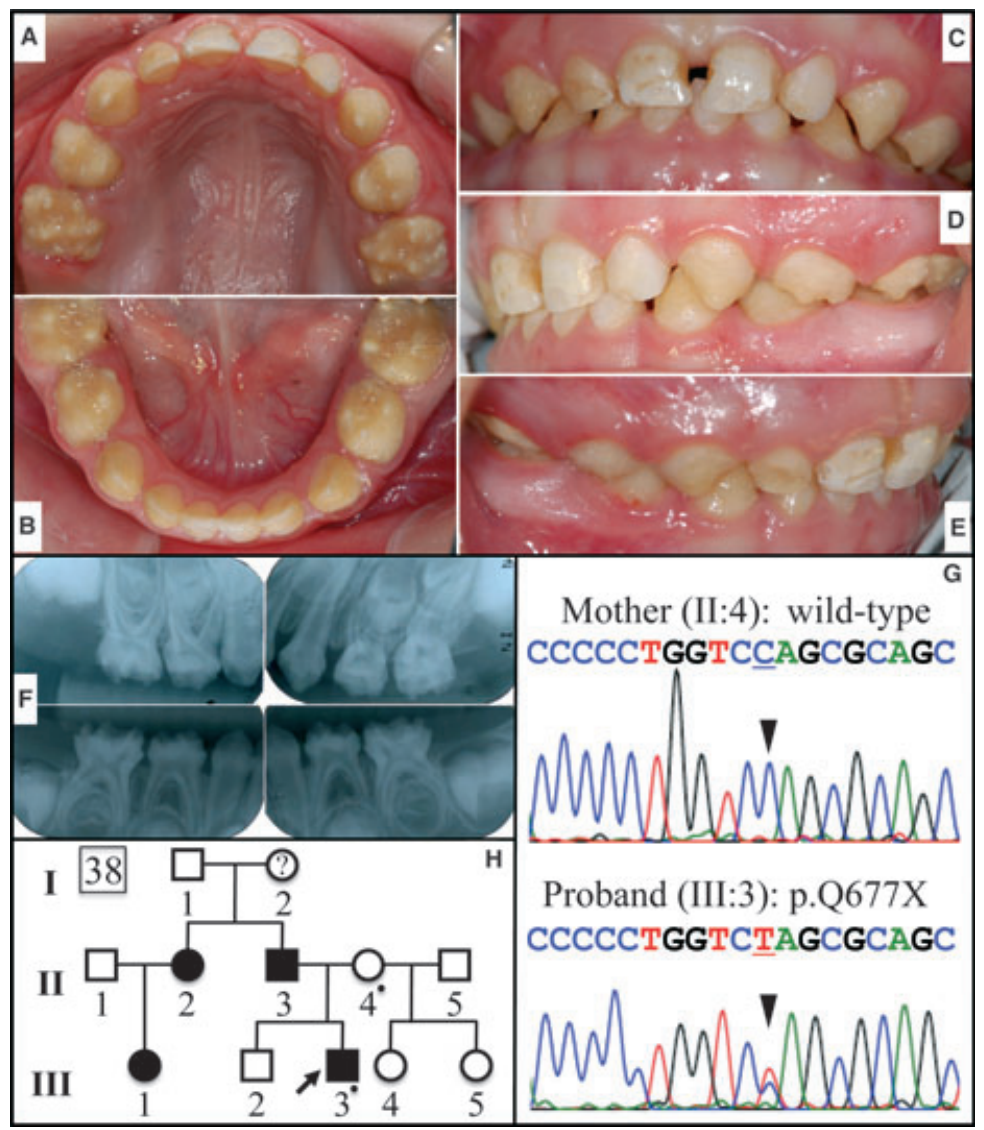

Fig. 4. Pedigree and sequencing chromatograms for family 38 (FAM83H, p.Q677X) and oral photographs and radiographs of the proband. This 3-yr-old Caucasian boy showed hypocalcified amelogenesis imperfecta (AI) in his primary dentition. (A) Maxillary occlusal, (B) mandibular occlusal, (C) frontal, (D) left buccal, (E) right buccal, (F) radiographs, (G) DNA-sequencing chromatograms showing a $\mathrm{C} / \mathrm{T}$ doublet demonstrating the c.2029 $\mathrm{C}>\mathrm{T}$ mutation in the proband, but not in the unaffected mother, and $(\mathrm{H}) \mathrm{a}$ pedigree showing the autosomal-dominant pattern of inheritance (a dot marks each person recruited in the study).

defective amelogenin during amelogenesis, depending upon which X-chromosome had been inactivated by the individual cells that later developed into ameloblasts $(2$, $25)$. The severity of the enamel phenotype in women can be influenced by skewed X-inactivation, where a disproportionate number of cells inactivate the X-chromosome carrying the mutant, or alternatively, the normal allele (26). The enamel phenotype in subjects with $A M E L X$ defects generally correlates with the nature of the $A M E L X$ mutation $(27,28)$. The phenotype in our family with the p.P70T defect in $A M E L X$ is consistent with previous descriptions of hypomineralization/hypomaturation enamel with brown discolouration (Figs 5, S1, and S2) (29-32).

Although amelogenins comprise $90 \%$ of the enamel matrix, only $5-10 \%$ of cases AI are X-linked. Abundance of the protein product is not a factor in determining the relative importance of $A M E L X$ in the aetiology of AI, which is a collection of many diseases exhibiting isolated enamel malformations. The number of AI-causing genes relates to the number of genes specialized for dental enamel formation (i.e. a loss of function would result in isolated enamel defects) plus the number of genes that function in multiple places, but enamel formation is most sensitive to their absence or alteration. Even if we knew the number of genes involved in the aetiology of AI, their individual contributions (in percentages of the total number of cases) would vary significantly, depending upon the number of mutations in each gene that could cause AI, the chances of these mutations occurring, and whether the resulting phenotypes would be dominant or recessive. Identifying the pantheon of genes that cause AI, and understanding their pathogenesis and mode of inheritance will allow us to appreciate the contributions of individual genes to the aetiology of AI as a whole.

\section{Autosomal-dominant Al}

About $46 \%$ of our AI kindreds showed a dominant pattern of inheritance, which is a lower proportion than found in Sweden ( 61\%) (33). It is likely, however, that a few of the remaining 11 simplex cases will prove to be dominant mutations. Most of the autosomal-dominant AI (ADAI) in our kindreds (12 out of 18 cases) was caused by defects in ENAM or FAM83H.

To date, 11 different disease-causing ENAM mutations have been reported (Table 3). ENAM defects show a dose effect (34). When one allele is defective the phenotype can range from non-penetrant (35), to minor 


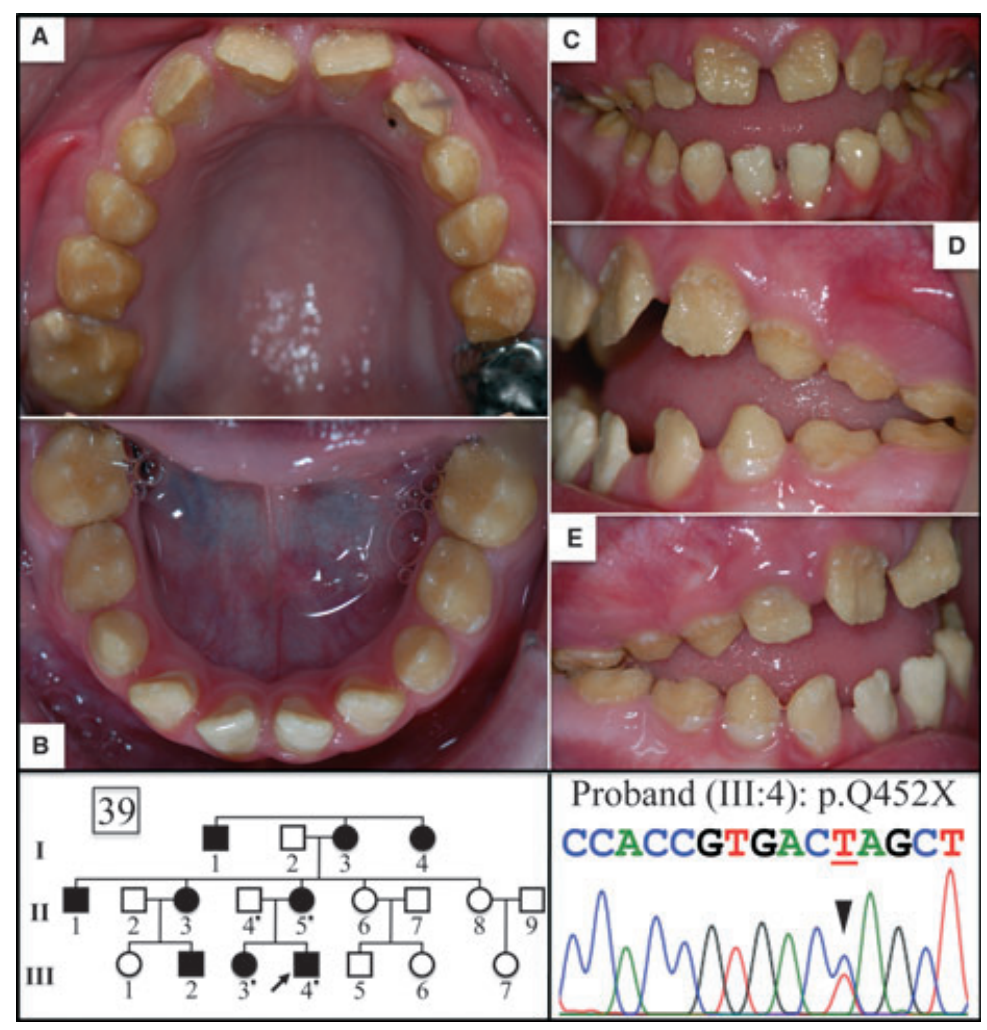

Fig. 5. Pedigree and DNA-sequencing chromatograms for family 39 (FAM83H, p.Q452X) and oral photographs of the 8-yr-old proband. The sequencing chromatogram shows a $\mathrm{C} / \mathrm{T}$ doublet demonstrating the c.1354C $>\mathrm{T}$ mutation in one $F A M 83 H$ allele. (A) maxillary occlusal, (B) mandibular occlusal, (C) frontal, (D) left buccal, and (E) right buccal. The phenotype in this Caucasian family is representative of autosomal-dominant hypocalcified amelogenesis imperfecta (ADHCAI).

well-circumscribed pits or horizontal grooves $(13,20$, 34,36 ), to pronounced horizontal grooves (37) with generally very thin enamel $(38,39)$, to virtually no enamel (13). When both ENAM alleles are defective, there is extreme enamel hypoplasia or no enamel $(20,34,35$, 40). In all four reported cases where both ENAM alleles are defective, one or both alleles had the p.V422PfsX448 mutation. In one case where the enamel was extremely thin and smooth, there was also defective eruption and coronal resorption (40), which we hypothesize was caused by secondary pathology in the enamel organ. The ameloblast layer becomes increasingly pathological as amelogenesis progresses in the absence of a true enamel layer in the Enam null mice $(41,42)$.

Although only recently discovered to be part of the aetiology of inherited enamel defects, FAM83H accounts for more cases of ADAI than any other gene. This was true for this study and also for another study that performed mutational analyses on 91 families with inherited enamel defects, 71 of which satisfied the classical criteria for non-syndromic AI (32). FAM83H encodes an intracellular protein of unknown function that appears to be associated with the Golgi apparatus or trans-Golgi network (19), and is most strongly expressed by pre-ameloblasts (43). In the last few years, 18 different FAM $83 H$ disease-causing mutations have been reported (Table 4). All of the defects are missense or frameshift mutations located within a discrete region of the last exon that truncate the protein and apparently target it to the nucleus (44). The $\mathrm{N}$-terminal region is the only part of the mutant proteins that is translated. This domain shares homology with the phospholipase D superfamily and is assumed to form dimers or to interact with another protein to cause dominant-negative effects in ameloblasts or their progenitors.

Defects in FAM83H cause autosomal-dominant hypocalcified AI (ADHCAI). The enamel layer has normal thickness in newly erupted teeth, but is rapidly lost by attrition following eruption and the teeth turn brown. Enamel that is not lost by attrition can sometimes persist indefinitely, such as islands of normal enamel. In this report we show the oral phenotypes of two new cases of hypocalcification AI caused by FAM $3 H$ defects. The first is the primary dentition of a Caucasian 3-yr-old boy with a p.Q677X mutation in FAM83H (Fig. 4). The second is a Caucasian family with a p.Q452X mutation (Figs 5, S2, and S3).

Some isolated cases of ADAI may come from defects in genes associated with syndromic AI. Collagen, type XVII, alpha 1 (COL17A1) contributes to the aetiology of junctional epidermolysis bullosa, a recessive disorder showing skin fragility, and AI (45). Mutations in a single allele of COL17A1 can cause isolated enamel defects $(46,47)$ or enamel defects combined with relatively minor skin fragility (48). Amelogenesis imperfecta can also occur along 
Table 2

Amelogenin (AMELX) disease-causing mutations

\begin{tabular}{lcccc}
\hline & & & \\
\hline
\end{tabular}

AMELX gene structure: numbered boxes indicate exons; introns are lines connecting the exons. Shaded exon regions are non-coding. The numbers below each exon show the range of amino acids encoded by it. Bold numbers indicate $A M E L X$ mutations. Mutation 5 is the deletion indicated by dashed lines. The gene numbers start from the first nucleotide of the $A M E L X$ reference sequence NG_012040.1. The cDNA numbers start from the translation initiation site of AMELX reference sequence NM_182680.1.

Table 3

Enamelin (ENAM) disease-causing mutations

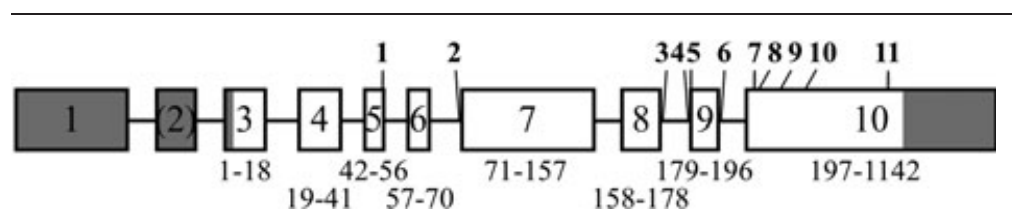

\begin{tabular}{|c|c|c|c|c|}
\hline No. & Gene & cDNA & Protein & References \\
\hline 1 & g. $3139 \mathrm{~A}>\mathrm{T}$ & c. $157 \mathrm{~A}>\mathrm{T}$ & p.K53X & 11,37 \\
\hline 2 & g. $55636 \mathrm{~A}>\mathrm{C}$ & c. $211-2 \mathrm{~A}>\mathrm{C}$ & p.M71_Q157del & 13 \\
\hline 3 & g.7152G > A & c. $534+1 \mathrm{G}>\mathrm{A}$ & p.A158_Q178del & 76,77 \\
\hline 4 & g. $9045 \mathrm{~A}>\mathrm{G}$ & c. $535-2 \mathrm{~A}>\mathrm{G}$ & p.R179-N196del & 32 \\
\hline 5 & g. $9048 \mathrm{G}>\mathrm{T}$ & c. $536 \mathrm{G}>\mathrm{T}$ & p.R179M & 78 \\
\hline 6 & g. $(9095-9101)$ delG & c. $(583-588+1) \mathrm{delG}$ & p.R179-N196del (or p.N197fsX277) & $13,36,38,39)$ \\
\hline 7 & g. $13330 \mathrm{C}>\mathrm{T}$ & c. $647 \mathrm{G}>\mathrm{T}$ & p.S216L & 20 \\
\hline 8 & g. $13420 \mathrm{C}>\mathrm{A}$ & c. $737 \mathrm{C}>\mathrm{A}$ & p.S246X & 34 \\
\hline 9 & $*$ & $\dagger^{\dagger}$ & $\ddagger$ & 34 \\
\hline 10 & g.13942_13943/insAG & c.1259_1230insAG & p.V422PfsX448 & $20,34-36,40,79$ \\
\hline 11 & g. $1 \overline{5} 674 \mathrm{delT}$ & c. $2991 \mathrm{delT}$ & p.L998WfsX1062 & 35 \\
\hline \multicolumn{5}{|c|}{ Both $E N A M$ alleles affected } \\
\hline No. & Allele 1 & Allele 2 & References & \\
\hline 1 & p.S216L & p.V422PfsX448 & 20 & \\
\hline 2 & p.V340_M341insSQYQYCV & p.V422PfsX448 & 34 & \\
\hline 3 & p.V422PfsX448 & p.V422PfsX448 & 35,40 & \\
\hline
\end{tabular}

ENAM gene structure: numbered boxes indicate exons; introns are lines connecting the exons. The numbers below each exon show the range of amino acids encoded by it. Shaded exon regions are non-coding. Bold numbers indicate ENAM mutations. The gene numbers start from the first nucleotide of the ENAM reference sequence NG_013024.1. The cDNA numbers start from the translation initiation site of ENAM reference sequence NM_031889.2.

*g.13703_13704insAGTCAGTACCAGTACTGTGTC;

†c.1020_1021insAGTCAGTACCAGTACTGTGTC;

*p.V340_M341insSQYQYCV 
Table 4

Family with sequence similarity 83, member $H$ (FAM83H) disease-causing mutations

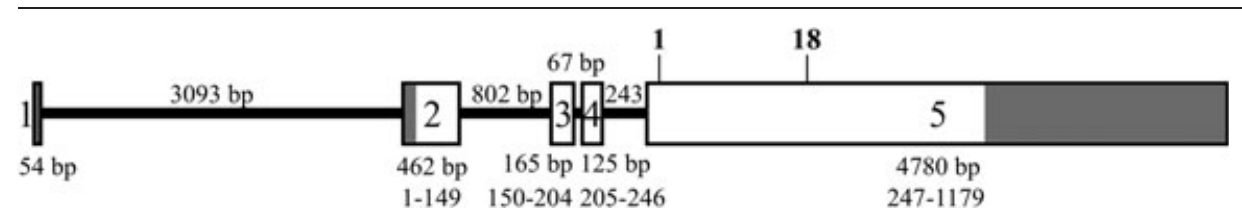

\begin{tabular}{|c|c|c|c|c|}
\hline No. & Gene & cDNA & Protein & References \\
\hline 1 & g. $5411 \mathrm{C}>\mathrm{A}$ & c. $860 \mathrm{C}>\mathrm{A}$ & p.S287X & 80 \\
\hline 2 & g. $5175 \mathrm{~T}>\mathrm{A}$ & c. $891 \mathrm{~T}>\mathrm{A}$ & p.Y297X & 64 \\
\hline 3 & g.5207_5208delTC & c.923_924delTC & p.L308fsX323 & 80 \\
\hline 4 & g. $5 \overline{2} 57 \mathrm{C}>\mathrm{T}$ & c. $. \overline{77} 3 \mathrm{C}>\mathrm{T}$ & p.R325X & 14 \\
\hline 5 & g. $5476 \mathrm{C}>\mathrm{T}$ & c. $1192 \mathrm{C}>\mathrm{T}$ & p.Q398X & $14,19,32,81$ \\
\hline 6 & g. $5528 \mathrm{G}>\mathrm{T}$ & c. $1243 \mathrm{G}>\mathrm{T}$ & p.E415X & 64 \\
\hline 7 & g. $5573 \mathrm{C}>\mathrm{A}$ & c. $1289 \mathrm{C}>\mathrm{A}$ & p.S430X & 32 \\
\hline 8 & g. $5614 \mathrm{C}>\mathrm{T}$ & c. $1330 \mathrm{C}>\mathrm{T}$ & p.Q444X & 19,81 \\
\hline 9 & g. $5638 \mathrm{C}>\mathrm{T}$ & c. $1354 \mathrm{C}>\mathrm{T}$ & pQ452X & 82 (here) \\
\hline 10 & g. $5650 \mathrm{C}>\mathrm{T}$ & c. $1366 \mathrm{C}>\mathrm{T}$ & p.Q456X & 81 \\
\hline 11 & g. $5658 \mathrm{C}>\mathrm{A}$ & c. $1374 \mathrm{C}>\mathrm{A}$ & p.Y458X & 83 \\
\hline 12 & g. $5663 \mathrm{G}>\mathrm{A}$ & c. $1379 \mathrm{G}>\mathrm{A}$ & p.W460X & 80 \\
\hline 13 & g. $5664 \mathrm{G}>\mathrm{A}$ & c. $1380 \mathrm{G}>\mathrm{A}$ & p.W460X & 64 \\
\hline 14 & g. $5692 \mathrm{G}>\mathrm{A}$ & c. $1408 \mathrm{C}>\mathrm{T}$ & p.Q470X & 80 \\
\hline 15 & g.6156_6157delCC & c.1872_1873delCC & p.L625fsX703 & 80 \\
\hline 16 & g. $6277 \mathrm{C}>\mathrm{T}$ & c. $1993 \mathrm{C}>\mathrm{T}$ & p.Q665X & 44 \\
\hline 17 & g. $6313 \mathrm{C}>\mathrm{T}$ & c. $2029 \mathrm{C}>\mathrm{T}$ & p.Q677X & $32,44,64$ (here) \\
\hline 18 & g. $6364 \mathrm{G}>\mathrm{T}$ & c. $2080 \mathrm{G}>\mathrm{T}$ & p.E694X & 80 \\
\hline
\end{tabular}

FAM $83 \mathrm{H}$ gene structure: numbered boxes indicate exons; introns are lines connecting the exons. The numbers above each intron indicate the length of the intron in base pairs (bp). The numbers below each exon show the length of the exon in bp and below that the range of amino acids encoded by it. Shaded exon regions are non-coding. The 17 reported FAM83H missense or frameshift mutations are located between the sites marked 1 and 17 in bold. The gene numbers start from the first nucleotide of the $F A M 83 H$ reference sequence NG_016652.1. The cDNA numbers start from the translation initiation site of FAM83H reference sequence NM_198488.3.

with nephrocalcinosis. Although nephrocalcinosis can be associated with impaired renal function, it is often asymptomatic and may go undiagnosed $(49,50)$. The genetic aetiology of this condition is currently unknown.

\section{Autosomal-recessive Al}

The diversity of enamel phenotypes in autosomal-recessive AI (ARAI) suggests that a large number of genes are involved in its aetiology (51). Only 10 mutations (in KLK4, MMP20, and WDR72) causing ARAI have been reported (Table 5). Consanguinity is a major contributor, as in all cases the same gene defect was observed in both alleles. Six of our 39 AI kindreds are known to have autosomal-recessive transmission patterns, and three of the causative mutations have been characterized in this group. We suspect that most of our simplex cases will turn out to be recessive conditions, as was determined for our kindred 33.

MMP20 is and KLK4 are secreted proteases that cleave amelogenin, ameloblastin, and enamelin in developing teeth (52). Cleavage of amelogenin reduces its affinity for hydroxyapatite (53). Mmp20 cleaves enamel proteins during the secrectory stage and the cleavage products accumulate in the matrix. Klk4 is expressed in the maturation stage and degrades the accumulated organic matrix to facilitate its reabsorption into ameloblasts (54). The enamel produced by Mmp20 and Klk4 null mice is soft and chips away after the teeth erupt into function (55-58). Based upon their known roles in enamel formation, it is not surprising that MMP20 and KLK4 defects cause AI.

$W D R 72$ had no suspected role in enamel formation before it was shown, by genetic analyses, to cause AI (59). The gene is expressed by maturation-stage ameloblasts, and defects in both alleles cause hypomaturation AI. The teeth erupt with a creamy-brown colour, a rough texture, and reduced radiodensity when compared with normal enamel. Posteruptive changes vary, but the enamel can turn a deep orange-brown colour and undergo accelerated attrition, particularly on working surfaces. The five reported WDR72 disease-causing mutations were all truncation mutations in both alleles. Perhaps the deleted C-terminal domain performs an essential function in ameloblasts, although there are currently no data showing that the defective transcripts are translated into protein.

\section{Aetiology of ARAI}

The six proven candidate genes for AI account for about half of all AI cases (Table 1). Although the genes responsible for ADAI remain to be identified, less is known about the genetic aetiology of ARAI. So far, no AI-causing mutations have been identified in the genes encoding several proteins exported by ameloblasts, such 
Table 5

Autosomal-recessive amelogenesis imperfecta (ARAI)-causing mutations in kallikrein-related peptidase 4 (KLK4), enamelysin (MMP20), and WD repeat containing domain 72 (WDR72)

No. Gene cDNA

KLK4 disease-causing mutation

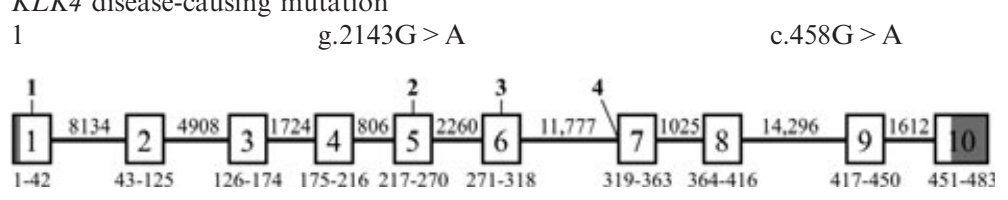

MMP20 disease-causing mutations
1
2
g. $115 \mathrm{G}>\mathrm{A}$
3
4

$$
\begin{gathered}
\text { c. } 102 \mathrm{G}>\mathrm{A} \\
\text { c. } 678 \mathrm{~T}>\mathrm{A} \\
\text { c. } 910 \mathrm{G}>\mathrm{A} \\
\text { c. } 954-2 \mathrm{~A}>\mathrm{T}
\end{gathered}
$$

$$
\begin{gathered}
\text { p.W34X } \\
\text { p.H226Q } \\
\text { p.A304T } \\
\text { IVS6-2ART }
\end{gathered}
$$
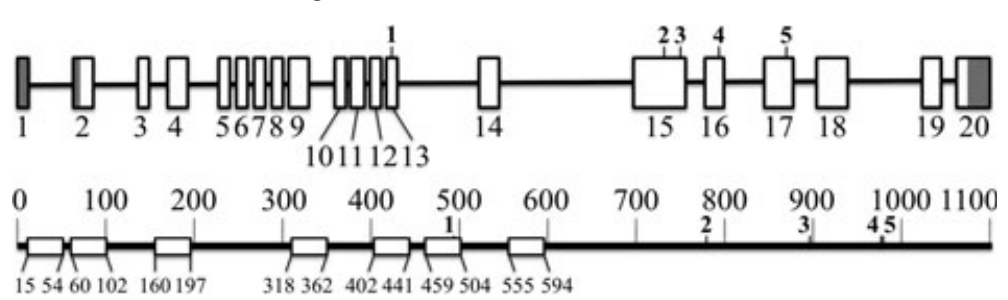

$155460102160197 \quad 318362402441459504555594$

WDR72 disease-causing mutations

\begin{tabular}{lccc}
1 & g.57,427_57,428delAT & c.1467_1468delAT & p.V491DfsX497 \\
2 & g. $143805 \mathrm{C}>\mathrm{G}$ & c. $2348 \mathrm{C}>\mathrm{G}$ & p.S783X \\
3 & g. $144143 \mathrm{C}>\mathrm{T}$ & c. $2686 \mathrm{C}>\mathrm{T}$ & p.R897X \\
4 & g. $145982 \mathrm{delA}$ & c. $2857 \mathrm{delA}$ & p.S976VX20 \\
5 & g.150132G $>$ A & c.2934G $>$ A & p.W978X \\
\hline
\end{tabular}

Exons are numbered boxes; introns are lines connecting the exons. The number below the intron indicates its length (in base pairs). The numbers below each exon show the range of amino acids encoded by it. Shaded exon regions are non-coding. Below the $W D R 72$ gene diagram is the WDR72 protein (1104 amino acids) showing the seven WD repeats (boxes), with the range of amino acids indicated below each. Mutation sites are numbered in bold. The gene numbers start from the first nucleotide of the genomic reference sequences (KLK4, NG_012154.1; MMP20, NG_012151.1; WDR72, NG_017034.1). The cDNA numbers start from the translation initiation site (KLK4, NM_004917.3; MMP20, NM_004771.3; WDR72, NM_182758.2).

as $A M B N(60)$, amelotin $(A M T N)(61)$, and odontogenic ameloblast-associated protein $(O D A M)(62)$. We suspect that these genes are involved in ARAI. The characterization of large consanguineous AI kindreds will continue to yield discoveries, but the application of whole-exome sequencing, which involves fragmenting genomic DNA and capturing coding sequences by hybridization to a chip, followed by next-generation DNA sequencing, is likely to yield important information concerning the diverse genetic aetiology of ARAI. This technique has recently been used to discover that $F A M 20 A$ is defective in subjects with $\mathrm{AI}$ and gingival hyperplasia syndrome (63).

Acknowledgements - We thank the family for their participation, and the Pediatric Dental Clinic at the University of Michigan for their cooperation. This investigation was supported by USPHS Research Grant DE015846 from the National Institute of Dental and Craniofacial Research (NIDCR),
National Institutes of Health (NIH), Bethesda, MD 29892, and a Science Research Center grant to the Bone Metabolism Research Center (2010-0001741) funded by the Ministry of Education, Science, and Technology (MEST) of Korea.

Conflicts of interest - All authors declare that there are no potential conflicts of interest.

\section{References}

1. Witкор CJ JR. Heterogeneity in inherited dental traits, gingival fibromatosis and amelogenesis imperfecta. South Med J 1971; 64 (Suppl 1):16-25.

2. Witkop CJ JR, SAuk JJ JR. Heritable defects of enamel. In: Stewart RE, Prescott GH, eds. Oral facial genetics. St. Louis: C.V. Mosby Co, 1976; 151-226.

3. WiткоP CJ JR. Amelogenesis imperfecta, dentinogenesis imperfecta and dentin dysplasia revisited: problems in classification. J Oral Pathol 1988; 17: 547-553. 
4. Simmer JP, Papagerakis P, Smith CE, Fisher DC, Rountrey AN, ZheNG L, Hu JC. Regulation of dental enamel shape and hardness. J Dent Res 2010; 89: 1024-1038.

5. Sмiтн CE. Cellular and chemical events during enamel maturation. Crit Rev Oral Biol Med 1998; 9: 128-161.

6. Sire JY, Delgado SC, Girondot M. Hen's teeth with enamel cap: from dream to impossibility. BMC Evol Biol 2008; 8: 246.

7. Davit-Beal T, Tucker AS, Sire JY. Loss of teeth and enamel in tetrapods: fossil record, genetic data and morphological adaptations. J Anat 2009; 214: 477-501.

8. Meredith RW, Gatesy J, Murphy WJ, Ryder OA, Springer MS. Molecular decay of the tooth gene Enamelin (ENAM) mirrors the loss of enamel in the fossil record of placental mammals. PLoS Genet 2009; 5: e1000634.

9. Meredith RW, Gatesy J, Cheng J, Springer MS. Pseudogenization of the tooth gene enamelysin (MMP20) in the common ancestor of extant baleen whales. Proc Biol Sci 2010; 278: 993-1002.

10. Al-Hashimi N, Lafont AG, Delgado S, Kawasaki $\mathrm{K}$, SIRE JY. The enamelin genes in lizard, crocodile, and frog and the pseudogene in the chicken provide new insights on enamelin evolution in tetrapods. Mol Biol Evol 2010; 27: 20782094.

11. Kim JW, Simmer JP, Lin BP, Seymen F, Bartlett JD, Hu JC. Mutational analysis of candidate genes in 24 amelogenesis imperfecta families. Eur J Oral Sci 2006; 114 (Suppl 1): 3-12.

12. Kim J-W, Simmer JP, Hu YY, Lin BP-L, Boyd C, Wright JT, Yamada CJM, Rayes SK, Feigal RJ, Hu JC-C. Amelogenin p.M1T and p.W4S mutations underlying hypoplastic X-linked amelogenesis imperfecta. $J$ Dent Res 2004; 83: 378-383.

13. Kim JW, Seymen F, Lin BP, Kiziltan B, Gencay K, Simmer JP, Hu JC. ENAM mutations in autosomal-dominant amelogenesis imperfecta. $J$ Dent Res 2005; 84: 278-282.

14. Kim JW, Lee SK, Lee ZH, Park JC, Lee KE, Lee MH, Park JT, Seo BM, Hu JC, Simmer JP. FAM83H mutations in families with autosomal-dominant hypocalcified amelogenesis imperfecta. Am J Hum Genet 2008; 82: 489-494.

15. Lee SK, Seymen F, Lee Ke, Kang Hy, Yildirim M, Tuna eB, Gencay K, Hwang YH, Nam KH, De La Garza RJ, Hu JC, Simmer JP, Kim JW. Novel WDR72 mutation and cytoplasmic localization. $J$ Dent Res 2010; 89: 1378-1382.

16. Hart PS, Hart TC, Michalec MD, Ryu OH, Simmons D, HoNG S, Wright JT. Mutation in kallikrein 4 causes autosomal recessive hypomaturation amelogenesis imperfecta. $J \mathrm{Med}$ Genet 2004; 41: 545-549.

17. Kim JW, Simmer JP, Hart TC, Hart PS, Ramaswami MD, BARTLETT JD, Hu JC. MMP-20 mutation in autosomal recessive pigmented hypomaturation amelogenesis imperfecta. $J$ Med Genet 2005; 42: 271-275.

18. Papagerakis P, Lin HK, Lee KY, Hu Y, Simmer JP, BartLETT JD, Hu JC. Premature stop codon in MMP20 causing amelogenesis imperfecta. $J$ Dent Res 2008; 87: 56-59.

19. Ding Y, Estrella MR, Hu YY, Chan HL, Zhang HD, Kim JW, Simmer JP, Hu JC. Fam83h is associated with intracellular vesicles and ADHCAI. J Dent Res 2009; 88: 991-996.

20. Chan HC, Mai L, Oikonomopoulou A, Chan HL, RichARDSON AS, WANG SK, SimMER JP, Hu JC. Altered enamelin phosphorylation site causes amelogenesis imperfecta. J Dent Res 2010; 89: 695-699.

21. BACKMAN B. Amelogenesis imperfecta - clinical manifestations in 51 families in a northern Swedish county. Scand J Dent Res 1988; 96: 505-516.

22. Luo W, Slavkin HC, Snead ML. Cells from Hertwig's epithelial root sheath do not transcribe amelogenin. J Periodontal Res 1991; 26: 42-47.

23. Hu JC, Sun X, Zhang C, Simmer JP. A comparison of enamelin and amelogenin expression in developing mouse molars. Eur J Oral Sci 2001; 109: 125-132.

24. Torres-Quintana MA, Gaete M, Hernandez M, Farias M, Lовоs N. Ameloblastin and amelogenin expression in posnatal developing mouse molars. J Oral Sci 2005; 47: 27-34.

25. Berkman MD, Singer A. Demonstration of the lyon hypothesis in X-linked dominant hypoplastic amelogenesis imperfecta. Birth Defects Orig Artic Ser 1971; 7: 204-209.
26. Hobson GM, Gibson CW, Aragon M, Yuan ZA, DavisWilliams A, Banser L, Kirkham J, Brook AH. A large Xchromosomal deletion is associated with microphthalmia with linear skin defects (MLS) and amelogenesis imperfecta (XAI). Am J Med Genet A 2009; 149A: 1698-1705.

27. Wright JT, Hart PS, Aldred MJ, Seow K, Crawford PJ, Hong SP, Gibson CW, HaRt TC. Relationship of phenotype and genotype in $\mathrm{X}$-linked amelogenesis imperfecta. Connect Tissue Res 2003; 44 (Suppl 1): 72-78.

28. Wright JT. The molecular etiologies and associated phenotypes of amelogenesis imperfecta. Am J Med Genet A 2006; 140 2547-2555.

29. Collier PM, Sauk JJ, Rosenbloom SJ, Yuan ZA, Gibson $\mathrm{CW}$. An amelogenin gene defect associated with human Xlinked amelogenesis imperfecta. Arch Oral Biol 1997; 42: 235 242.

30. Hart S, Hart T, Gibson C, Wright JT. Mutational analysis of X-linked amelogenesis imperfecta in multiple families. Arch Oral Biol 2000; 45: 79-86.

31. Ravassipour DB, Hart PS, Hart TC, RitTer AV, Yamauch M, Gibson C, Wright JT. Unique enamel phenotype associated with amelogenin gene (AMELX) codon 41 point mutation. $J$ Dent Res 2000; 79: 1476-1481.

32. Wright JT, Torain M, Long K, Seow K, Crawford P, AlDRED MJ, HART PS, HART TC. Amelogenesis imperfecta: genotype-phenotype studies in 71 families. Cells Tissues Organs 2011; 194: 279-283.

33. Backman B, Holmgren G. Amelogenesis imperfecta: a genetic study. Hum Hered 1988; 38: 189-206.

34. Ozdemir D, Hart PS, Firatli E, Aren G, Ryu OH, Hart TC. Phenotype of ENAM mutations is dosage-dependent. $J$ Dent Res 2005; 84: 1036-1041.

35. Kang Hy, Seymen F, Lee SK, Yildirim M, Tuna EB, Patir A, LeE KE, KIm JW. Candidate gene strategy reveals ENAM mutations. J Dent Res 2009; 88: 266-269.

36. Pavlic A, Petelin M, Battelino T. Phenotype and enamel ultrastructure characteristics in patients with ENAM gene mutations g.13185-13186insAG and 8344delG. Arch Oral Biol 2007; 52: 209-217.

37. Mårdh CK, Backman B, Holmgren G, Hu JC, Simmer JP, FORSMAN-SEMB K. A nonsense mutation in the enamelin gene causes local hypoplastic autosomal dominant amelogenesis imperfecta (AIH2). Hum Mol Genet 2002; 11: 10691074.

38. Kida M, Ariga T, Shirakawa T, Oguchi H, Sakiyama Y. Autosomal-dominant hypoplastic form of amelogenesis imperfecta caused by an enamelin gene mutation at the exonintron boundary. J Dent Res 2002; 81: 738-742.

39. Hart PS, Michalec MD, Seow WK, Hart TC, Wright JT. Identification of the enamelin (g.8344delG) mutation in a new kindred and presentation of a standardized ENAM nomenclature. Arch Oral Biol 2003; 48: 589-596.

40. Lindemeyer RG, Gibson CW, Wright TJ. Amelogenesis imperfecta due to a mutation of the enamelin gene: clinical case with genotype-phenotype correlations. Pediatr Dent 2010; 32: $56-60$.

41. Hu JC, Hu Y, Smith CE, McKee MD, Wright JT, Yamakoshi Y, Papagerakis P, Hunter GK, Feng JQ, YAMAKoshi F, Simmer JP. Enamel defects and ameloblastspecific expression in Enam knock-out/lacz knock-in mice. $J$ Biol Chem 2008; 283: 10858-10871.

42. Sawada T, Sekiguchi H, Uchida T, Yamashita H, Shintani S, Yanagisawa T. Histological and immunohistochemical analyses of molar tooth germ in enamelin-deficient mouse. Acta Histochem 2010; 113: 542-546.

43. Lee MJ, Lee SK, Lee KE, Kang HY, Jung HS, Kim JW. Expression patterns of the Fam83h gene during murine tooth development. Arch Oral Biol 2009; 54: 846-850.

44. Lee SK, Lee Ke, Jeong TS, Hwang YH, Kim S, Hu JC, SimMER JP, KIM JW. FAM83H mutations cause ADHCAI and alter intracellular protein localization. $J$ Dent Res 2011; 89: 1378-1382.

45. WRIGHT JT. Oral manifestations in the epidermolysis bullosa spectrum. Dermatol Clin 2010; 28: 159-164. 
46. McGrath Ja, Gatalica B, Li K, Dunnill MG, McMillan JR, Christiano AM, Eady RA, Uitto J. Compound heterozygosity for a dominant glycine substitution and a recessive internal duplication mutation in the type XVII collagen gene results in junctional epidermolysis bullosa and abnormal dentition. Am J Pathol 1996; 148: 1787-1796.

47. Murrell DF, Pasmooij AM, Pas HH, Marr P, Klingberg S, Pfendner E, Uitto J, Sadowski S, Collins F, Widmer R, JONKMAN MF. Retrospective diagnosis of fatal BP180-deficient non-Herlitz junctional epidermolysis bullosa suggested by immunofluorescence (IF) antigen-mapping of parental carriers bearing enamel defects. J Invest Dermatol 2007; 127: 1772 1775 .

48. Almaani N, Liu L, Dopping-Hepenstal PJ, Lovell PA, LaiCheong Je, Graham RM, Mellerio JE, McGrath JA. Autosomal dominant junctional epidermolysis bullosa. $\mathrm{Br} J$ Dermatol 2009; 160: 1094-1097.

49. Kirzioglu Z, Ulu KG, Sezer MT, Yuksel S. The relationship of amelogenesis imperfecta and nephrocalcinosis syndrome. Med Oral Patol Oral Cir Bucal 2009; 14: e579-e582.

50. Martelli-Junior H, Santos Neto Pe, Aguino SN, Santos CC, Borges SP, Oliveira EA, Lopes MA, Coletta RD. Amelogenesis imperfecta and nephrocalcinosis Syndrome: a case report and review of the literature. Nephron Physiol 2011; 118: $\mathrm{p} 62-\mathrm{p} 65$.

51. Nusier M, Yassin O, Hart TC, Samimi A, Wright JT. Phenotypic diversity and revision of the nomenclature for autosomal recessive amelogenesis imperfecta. Oral Surg Oral Med Oral Pathol Oral Radiol Endod 2004; 97: 220230.

52. Lu Y, Papagerakis P, Yamakoshi $\mathrm{Y}, \mathrm{Hu}$ JC, Bartlett JD, SiMMER JP. Functions of KLK4 and MMP-20 in dental enamel formation. Biol Chem 2008; 389: 695-700.

53. Sun Z, Fan D, Fan Y, Du C, Moradian-Oldak J. Enamel proteases reduce amelogenin-apatite binding. $J$ Dent Res 2008; 87: 1133-1137.

54. Smith CE, Richardson AS, Hu Y, Bartlett JD, Hu JC, SimMER JP. Effect of kallikrein 4 loss on enamel mineralization: comparison with mice lacking matrix metalloproteinase 20 . J Biol Chem 2011; 286: 18149-18160.

55. Caterina JJ, Skobe Z, Shi J, Ding Y, Simmer JP, BirkedalHANSEN H, BARTLETT JD. Enamelysin (matrix metalloproteinase 20)-deficient mice display an amelogenesis imperfecta phenotype. J Biol Chem 2002; 277: 49598-49604.

56. Bartlett JD, Beniash E, Lee DH, Smith CE. Decreased mineral content in MMP-20 null mouse enamel is prominent during the maturation stage. $J$ Dent Res 2004; 83: 909-913.

57. Simmer JP, Hu Y, Lertlam R, Yamakoshi Y, Hu JC. Hypomaturation enamel defects in Klk4 knockout/LacZ knockin mice. J Biol Chem 2009; 284: 19110-19121.

58. Simmer J, Hu Y, Richardson A, Bartlett J, Hu JC-C. Why does enamel in Klk4 null mice break above the dentino-enamel junction? Cells Tissues Organs 2011; 194: 211-215.

59. El-Sayed W, Parry da, Shore RC, Ahmed M, Jafri H, Rashid Y, Al-Bahlani S, Al Harasi S, Kirkham J, InglehEARN CF, Mighell AJ. Mutations in the beta propeller WDR72 cause autosomal-recessive hypomaturation amelogenesis imperfecta. Am J Hum Genet 2009; 85: 699-705.

60. Krebsbach PH, Lee SK, Matsuki Y, Kozak CA, Yamada K, YAMADA Y. Full-length sequence, localization, and chromosomal mapping of ameloblastin: a novel tooth-specific gene. J Biol Chem 1996; 271: 4431-4435.

61. Inasaki K, Bajenova E, Somogyi-Ganss E, Miller M, Nguyen V, Nourkeyhani H, Gao Y, Wendel M, Ganss B. Amelotin - a Novel Secreted, Ameloblast-specific protein. J Dent Res 2005; 84: 1127-1132.

62. Moffatt P, Smith CE, Sooknanan R, St-Arnaud R, Nancl A. Identification of secreted and membrane proteins in the rat incisor enamel organ using a signal-trap screening approach. Eur J Oral Sci 2006; 114 (Suppl 1): 139-146.

63. O'Sullivan J, Bitu CC, Daly SB, Urquhart Je, Barron MJ, Bhaskar SS, Martelli-Junior H, Dos Santos Neto PE, Mansilla ma, Murray JC, Coletta RD, Black GC, Dixon MJ. Whole-exome sequencing identifies FAM20A mutations as a cause of amelogenesis imperfecta and gingival hyperplasia syndrome. Am J Hum Genet 2011; 88: 616-620.

64. Lee SK, Hu JC-C, Bartlett JD, Lee Ke, Lin BP-J, Simmer JP, KIM JW. Mutational spectrum of FAM $83 \mathrm{H}$ : the C-terminal portion is required for tooth enamel calcification. Hum Mutat 2008; 29: E95-E99.

65. Seriguchi H, Kiyoshi M, YakushiJ M. DNA diagnosis of $\mathrm{X}$-linked amelogenesis imperfecta using PCR detection method of the human amelogenin gene. Dent Japan 2001; 37: 109112.

66. Lagerstrom-Fermer M, Nilsson M, Backman B, Salido E, Shapiro L, Pettersson U, Landegren U. Amelogenin signal peptide mutation: correlation between mutations in the amelogenin gene (AMGX) and manifestations of X-linked amelogenesis imperfecta. Genomics 1995; 26: 159-162.

67. LENCH NJ, WINTER GB. Characterisation of molecular defects in X-linked amelogenesis imperfecta (AIH1). Hum Mutat 1995; 5: $251-259$.

68. Aldred MJ, Crawford PJ, Roberts E, Thomas NS. Identification of a nonsense mutation in the amelogenin gene (AMELX) in a family with X-linked amelogenesis imperfecta (AIH1). Hum Genet 1992; 90: 413-416.

69. LeNCH NJ, Brook AH, Winter GB. SSCP detection of a nonsense mutation in exon 5 of the amelogenin gene (AMGX) causing X-linked amelogenesis imperfecta (AIH1). Hum Mol Genet 1994; 3: 827-828.

70. Kida M, Sakiyama Y, Matsuda A, Takabayashi S, Ochi H, Sekiguchi H, Minamitake S, Ariga T. A novel missense mutation (p.P52R) in amelogenin gene causing X-linked amelogenesis imperfecta. J Dent Res 2007; 86: 69-72.

71. Hart PS, Aldred MJ, Crawford PJ, Wright NJ, Hart TC, WRIGHT JT. Amelogenesis imperfecta phenotype-genotype correlations with two amelogenin gene mutations. Arch Oral Biol 2002; 47: 261-265.

72. Sekiguchi H, Alaluusua S, Minaguchi K, Yakushiji M. A new mutation in the amelogenin gene causes X-linked amelogenesis imperfecta. $J$ Dent Res 2001; 80: 617

73. Greene SR, Yuan ZA, Wright JT, Amjad H, Abrams WR, Buchanan JA, Trachtenberg DI, Gibson CW. A new frameshift mutation encoding a truncated amelogenin leads to X-linked amelogenesis imperfecta. Arch Oral Biol 2002; 47: 211-217.

74. Lee K-E, Lee S-K, Jung S-E, Song SJ, Cho SH, Lee ZH, Kim $\mathrm{J}-\mathrm{W}$. A novel mutation in the AMELX gene and multiple crown resorptions. Eur J Oral Sci 2011; 119(Suppl. 1): 324-328.

75. Kindelan SA, Brook AH, Gangemi L, Lench N, Wong FS, Fearne J, Jackson Z, Foster G, Stringer BM. Detection of a novel mutation in X-linked amelogenesis imperfecta. $J$ Dent Res 2000; 79: 1978-1982.

76. Rajpar MH, Harley K, Laing C, Davies RM, Dixon MJ. Mutation of the gene encoding the enamel-specific protein, enamelin, causes autosomal-dominant amelogenesis imperfecta. Hum Mol Genet 2001; 10: 1673-1677.

77. Urzua ob, Ortega PA, Rodriguez ML, Morales BI. Genetic, clinical and molecular analysis of a family affected by amelogenesis imperfecta. Rev Med Chil 2005; 133: 1331-1340.

78. Gutierrez SJ, Chaves M, Torres DM, Briceno I. Identification of a novel mutation in the enamalin gene in a family with autosomal-dominant amelogenesis imperfecta. Arch Oral Biol 2007; 52: 503-506.

79. Hart tC, Hart PS, Gorry MC, Michalec MD, Ryu OH, Uygur C, Ozdemir D, Firatli S, Aren G, Firatli E. Novel ENAM mutation responsible for autosomal recessive amelogenesis imperfecta and localised enamel defects. $J$ Med Genet 2003; 40: 900-906.

80. Wright JT, Frazier-Bowers S, Simmons D, Alexander K, Crawford P, Han ST, Hart PS, Hart TC. Phenotypic variation in FAM83H-associated amelogenesis imperfecta. $J$ Dent Res 2009; 88: 356-360.

81. Hart PS, Becerik S, Cogulu D, Emingil G, Ozdemir-OzeNen D, Han ST, Sulima PP, Firatli E, Hart TC. Novel FAM83H mutations in Turkish families with autosomal dominant hypocalcified amelogenesis imperfecta. Clin Genet 2009; 75: $401-404$ 
82. Hyun HK, Lee SK, Lee KE, Kang Hy, Kim EJ, Choung PH, KIM JW. Identification of a novel FAM83H mutation and microhardness of an affected molar in autosomal dominant hypocalcified amelogenesis imperfecta. Int Endod $J$ 2009; 42: 1039-1043.

83. El-Sayed W, Shore RC, Parry Da, Inglehearn CF, MigHELL AJ. Ultrastructural analyses of deciduous teeth affected by hypocalcified amelogenesis imperfecta from a family with a novel Y458X FAM83H nonsense mutation. Cells Tissues Organs 2010; 191: 235-239.

84. Ozdemir D, Hart PS, Ryu OH, Choi SJ, Ozdemir-Karatas M, Firatli E, Piesco N, Hart TC. MMP20 active-site mutation in hypomaturation amelogenesis imperfecta. J Dent Res 2005; 84: 1031-1035.

85. Lee SK, Seymen F, Kang Hy, Lee Ke, Gencay K, Tuna B, KIM JW. MMP20 hemopexin domain mutation in amelogenesis imperfecta. J Dent Res 2010; 89: 46-50.

86. El-Sayed W, Shore RC, Parry DA, Inglehearn CF, Mighell AJ. Hypomaturation amelogenesis imperfecta due to WDR72 mutations: a novel mutation and ultrastructural analyses of deciduous teeth. Cells Tissues Organs 2011; 194: 60-66.

\section{Supporting Information}

Additional Supporting Information may be found in the online version of this article:

Fig. S1. Oral photographs and radiographs of the family 37 (AMELX, pP70T) proband at age 11.5.

Fig. S2. Oral photographs of the unaffected father (II:4) of family 37 (AMELX, pP70T).

Fig. S3. Oral photographs for family 39 (FAM83H, pQ452X).

Please note: Wiley-Blackwell is not responsible for the content or functionality of any supporting materials supplied by the authors. Any queries (other than missing material) should be directed to the corresponding author for the article. 